\title{
The Calcutta Chromosome: An Acknowledgement of Indigenous Caliber and Extrapolation upon the History of Malaria Parasite Discovery
}

\author{
Manoj Kumar Pathak \\ Arka Jain University, \\ 312/A Gamharia District, Jamshedpur, 832108, Republic of India \\ $\checkmark$ mkp4ujsr@gmail.com
}

\begin{abstract}
Amitav Ghosh' novel The Calcutta Chromosome: a Novel of Fevers, Delirium and Discovery is considered, - an outstanding literary work in which the writer reveals a discourse of science versus counter-science from the earlier world of social, cultural and ethnical history of Indian subcontinent. India is home to the oldest continuous civilization, nevertheless, the long invasive rule of the Mughals and the Britishers has framed minds to undervalue the indigenous knowledge, practices, customs and discourses. Amitav Ghosh' novel denies the Western supremacy in every field and puts a question mark in the invention of Anopheles maculipennis as the cause of malaria. Dr. Ronald Ross received the prestigious Nobel Prize in 1902 for his discovery of malaria parasite but Amitav Ghosh supports the contribution of Indian assistants Mangala and Laakhan who were not acknowledged by the British researchers. The novel reflects a postcolonial approach to interpret Western scientific mechanism, posits the question to unethical exploitation of native workers by the English and gives voice to the traditional knowledge of the subalterns. An integral part of Ghosh's approach in this novel is to illuminate the richness of ideas and complexity of Indigenous life, and to create a place where aboriginals are acknowledged for their remarkable contributions.
\end{abstract}

Keywords: indigenous, subalterns, native, extrapolation, voice

Conflicts of interest. The author declares that there is no conflict of interest.

Article history: submitted December 12, 2020; revised December 29, 2020; accepted January 9, 2021.

For citation: Pathak, M.K. (2021). The Calcutta Chromosome: An acknowledgement of indigenous caliber and extrapolation upon the history of malaria parasite discovery. RUDN Journal of Studies in Literature and Journalism, 26(1), 79-84. http://dx.doi.org/10.22363/ 2312-9220-2021-26-1-79-84 


\title{
Роман Амитава Гоша «Хромосома Калькутты»: признание роли коренных жителей в открытии малярийных паразитов
}

\author{
М.К. Патхак \\ Университет Арка Джайн, \\ Республика Индия, 832108, Джамшедпур, р-н Гамхария, д. 312/A \\ $\checkmark$ mkp4ujsr@gmail.com
}

\begin{abstract}
Аннотация. Рассматривается роман Амитава Гоша «Хромосома Калькутты: роман о лихорадках, бреде и открытиях», являющийся выдающимся литературным произведением, в котором писатель раскрывает дискурс науки и контрнауки на примере явлений социальной, культурной и этнической истории Индостана. Индия - очаг древнейшей цивилизации, однако продолжительное вторжение Великих Моголов и длительный период колонизация британцами привели к недооцениванию знаний, обычаев и дискурсов коренных народов. В своем романе Амитав Гош отрицает превосходство Запада во всех областях и ставит под вопрос приоритет открытия комара Anopheles maculipennis как источника малярии. Как известно, доктор Рональд Росс получил престижную Нобелевскую премию в 1902 году за открытие малярийного паразита, но Амитав Гош показывает в романе, что вклад индийских помощников Мангала и Лаакхана, которые не были признаны британскими исследователями, сильно недооценен. Роман отражает постколониальный подход к интерпретации западного научного механизма, ставит вопрос о неэтичности эксплуатации англичанами коренных рабочих и является важным вкладом писателя в утверждение ценности традиционных знаний и культуры индусов. Замечательной чертой подхода Гоша в этом романе явилось то, что он подчеркивает особое богатство идей и многослойности жизни коренных народов, а также создает такое место, где аборигены получают признание за свой выдающийся вклад.
\end{abstract}

Ключевые слова: коренные жители, подчиненные, аборигены, экстраполяция, голос

Заявление о конфликте интересов. Автор заявляет об отсутствии конфликта интересов.

История статьи: поступила в редакцию 12 декабря 2020 г.; принята к публикации 9 января 2021 г.

Для цитирования: Pathak M.K. The Calcutta Chromosome: an acknowledgement of indigenous caliber and extrapolation upon the history of malaria parasite discovery // Вестник Российского университета дружбы народов. Серия: Литературоведение. Журналистика. 2021. T. 26. № 1. C. 79-84. http://dx.doi.org/10.22363/2312-9220-2021-26-1-79-84

\section{Introduction}

India after independence suffers from identity crisis in different fronts. The continuous and hostile rule of invaders and foreigners undermined the real identity and when the British left India, it was left with confusion, distress, aimlessness and clouds of despair. The Indians haunted for peace, harmony, rest and the real 'self'. M.K. Naik and Shyamala A. Narayan in Indian English Literature: 
1980-2000: A Critical Survey rightly defines the situation while analyzing the Midnight's Children:

"Identity is in turn, shown as a sham, as mistaken and confused, subjected to oblivion, fractured, dwarfed and reduced to animal level; as barren, sterile and totally lost. And since heredity is an essential element in identity, some of these ordeals are repeated from generation to generation in the narrative which opens with the protagonist's grandfather and ends with his son" [1. P. 40].

There upon started the age of experiments and the portrayal of newer themes. Besides, partition, 'undocumented history' started to be recognized and re-asserted by the novelists. Novels written initially with marginal voices are Raj Kamal Jha's The Blue Bedspread and If You are Afraid of Heights, Ram Chandra Prasad's The Mahatma, S.D. Singh's The Raja's Mistress and Prema Nanda Kumar's Atom and the Serpent.

\section{The author:}

\section{translocating the power end and the annals of history}

Amitav Ghosh, belonging to an elite Bengali family lineage, turns his sight of keen observation to the indigenous, the margins. He is an impassioned writer who documents the 'undocumented' and the 'unhistorical'. He re-drafts the past. He charts history with novel vision and insight. Almost all of his novels depict the hardships and deadlocks of the deprived lot and their life-journey. He is a sensitive writer who endows his fiction with the concerns of the marginalized and that too with eloquence of expression. He takes help of imagination, myth, folk-tales and varied narrative devices to strengthen his content; not to hamper his saying or thematic concern. We find a master-use of form in the novels of Amitav Ghosh to support the theme concerned. Lionel Trilling in his book The Liberal Imagination defines modern novel as 'a perpetual quest for reality and is the most effective agent of the moral imagination' [2. P. 212]. Ghosh accomplishes his fiction to perceive the lives of the people who lack identity and heed of the majority; compelling them to be deprived of the basic human entities. The constant concern with the subaltern, who's lost in the annals of history, endears him to the readers. Annada Shankar Ray, a renowned novelist, comments on the contemporary novel: "When Bankim wrote, the chief question was how to restore the national self-respect. In Rabindranath's time, it was how to bridge the East and the West. In this dynamic age, it is how to identify ourselves with the common people" [3. P. 317] and Ghosh is fit to the very dynamism, and in all of his novels he reconstructs newer identities.

The Western scholars tried to demean the Indian traditions of knowledge. The disgraceful comment made by Macaulay in his Minutes of Education (1835) regarding the educational funding to run the indigenous schools (Pathshalas and Gurukuls) manifests the derogatory thought of the Anglicists for the Indian body of knowledge and practices. He argues against the sanction of funds saying that Indian educational system should not be funded because it caters such:

"Medical doctrine which would disgrace an English farrier, astronomy which would move laughter in girls at an English boarding school, history abounding with kings thirty feet high and reigns thirty thousand years long, and geography made up of seas of treacle and seas of butter" [4. P. 1835]. 
India is a multicultural nation and it is not an easy walk to define identity in Indian perspective. Amitav Ghosh vows to identify the 'unidentified'. The problematic predicaments of the post-colonial India are the major concerns of the author under study. Even though, he has many a time refused to state him a 'post-colonial' novelist, yet his fiction represents the voices of the post-colonial Indian subcontinent; especially the disparaged who bear no defined identity or who are not restricted to particular territorial borders and are bound to be on move throughout the life. He has depicted the causes and consequences of migration in a sensible and responsible way. It is pertinent to note in this context that migration is an offshoot of post-coloniality and hence the theme of migration and the plight of the post-colonial migrants constitute the subject of almost all of his novels [5-7].

\section{The Calcutta Chromosome: articulating silences and re-directing the notion}

In The Calcutta Chromosome, a novel published in 1996, Amitav Ghosh tries on mixing fantasy, horror, science-fiction and counter-science. This work was widely appreciated for its extrapolation upon the history of malaria parasite discovery. Experimenting with form is a common feature of post-colonial writings but Ghosh is somehow more interested and at home in it. Even though, the substance of the novel is on scientific research, yet Ghosh continues to project Indian ethos in his fiction. The present novel too, raises the voices of those who were undermined by the Westerners. Mangala bibi is a character who plays secretly. Her secrecy is a major tool to highlight typical Indian belief, myth, spiritual practices and their effectiveness. Ghosh puts forward the counter-science practiced and represented by Mangala bibi, the assistant to D.D. Cunningham. Mangala is symbolic to Indian mysticism and supernatural powers often neglected by the Westerners. Ghosh draws the attention towards the age-long practices prevalent in India and projects it as a counter-science which complements to the main-stream science. Mangala is a washer-woman representing the marginals. Mangala is characterized to assert the importance of the marginals who cannot be underestimated as they too are knowledgeable enough to complement the formal science. Mangala is a woman of her own traits; the archetypal 'shakti swarupa'.

The Calcutta Chromosome focuses on the peripheral. The story develops through the margins. Murugan, the central character too seems marginalized when the scientific community or his employer labels him 'as a crank and an eccentric'. Lakhan is also a subaltern character who is sometimes called Lutchman. He was recovered at the Sealdah station and worked at the lab with Cunningham. He is again taken to Renupur where he has a new identity. Ghosh instates the Indian subalterns in place of the Westerners. The characters are given more than a name which clarifies the novelist's intention to destabilize the fixed identity and this is a postcolonial phenomenon. Lakhan, Mangala and Phulboni have more than a name; re-crafting their identities and standing before centrism. The shadow lines between the elite and subaltern subjects have been brought to light in this novel.

Ghosh sketches the character Murugan who is desperate and intense for demystifying the truth behind the malaria parasite discovery. Murugan exposes a subtext of counter-science in Ross's laboratory. Urmila, a journalist joins Muru- 
gan and they theorize that Ross was sloppy, intent on fame and fortune. His discoveries were fed to him by his Indian aides and among them Mangala, his laboratory technologist was the most important person who had high spiritualistic ambitions. Mangala stealthily practiced some traditional ways to cure some diseases and Murugan finds that Mangala anticipated the later discovery of another Nobel laureate J. Wagner-Jauregg, who propounded the use of malaria for the treatment of syphilis. Murugan and Urmila travel extensively in Calcutta to find that the views of traditional knowledge and practice as of great importance still wait for their own discovery. Ghosh makes Murugan and Urmila his mouthpiece to deconstruct Western discovery and forced supremacy.

\section{Creating indigenous narratives: extrapolating upon history}

Murugan was rightly thinking that a 'counter-scientific' discourse had engineered Ross's discoveries secretly. It is thoroughly found that some figures of indigenous connections are leading this cult, namely Mangala, a cleaning ladyattendant supported by a 'dhooley bearer' Lutchman who is also known as Lakshman and Laakha. According to Murugan, "to know something is to change it, because as soon as something is known, it is already changed. Since, by then you only know its history" [8. P. 60]. The text frames a counter-narrative that draws an inference that the counter-scientific group, that is, the indigenous attendants of Dr. Ross, was way ahead of the Western researches in its research with a clear understanding that the malaria vector is the female Anopheles mosquito. Murugan projects his view that Mangala and Lutchman manipulated Ross's discovery in order to be acknowledged by Nobel Prize for the malaria parasite discovery. Ghosh establishes here that discourses, discoveries and derivations of science, technology, medicine or of any discipline cannot be described as a one way process of transfer from the West to the East rather, cross-cultural transaction.

Ghosh becomes voice of the voiceless people. His fiction reflects his interest to re-create history and construct a glass-palace of newer facts related to the dispossessed and subaltern community. Ghosh re-narrates the stories of past with inclusion of those whose moves have been kept buried. It is a current trend to read and analyze the past in perspective of the marginalized; Amitav Ghosh seems to connect those stories with the documented history. The novels of Amitav Ghosh are the records of ordinary lives in contrary to the prejudiced traditional historiography which is only the one side of the facet. Ghosh through his characters re-asserts and re-defines the categorization of the colonizer-colonized, Westerner-Indian and powerful-powerless. The critics have demonstrated how Ghosh has questioned and subverted the Western notion and objective of scientific researches and technological applications.

History for Ghosh no longer remains mere (hi)story. Furthermore, he explores the various dimensions of the colonial history that projects indigenous narratives, knowledge, practices and customs as of no significance and rationality. He re-drafts history to determine the indigenous identity of a race or nation as a whole. The Anglicized history also attracts his attention, to analyze the politics 
of history in the postcolonial world, which remains submerged in politics of identity. Historical facts have mostly been documented to pacify a certain class and the tormenting parts have not been duly presented.

\section{Conclusion}

Amitav Ghosh, as an author, has attempted to raise and amplify the voice of the indigenous or subaltern people, and place them in the context of history they had been long denied. He re-interprets history, records the lives of common people, their participation, contribution and predicaments in most of his novels. Ghosh here too in The Calcutta Chromosome portrays the 'unhistorical people' in his canvas of fiction. The re-invention of history creates an atmosphere for new debates and discourses. Ghosh's depiction of history re-shapes the past and reconstructs the identities of the marginalized people. Ghosh includes the underprivileged as a deliberate strategy in his writings to recognize the postcolonial world, and to safeguard the rights of truth associated with the indigenous people. He justifies their contributions to the human race. He advocates and claims for the dignity of the unheard lot. Ghosh has meticulously attempted to highlight the contributions of the postcolonial common and neglected subjects in different arena of discourses and he articulates the silences in his texts to create indigenous narratives of resistance.

\section{References}

[1] Naik, M.K., \& Narayan S.A. (2009). Indian English fiction 1980-2008: New bearings and fresh flowering. Indian English Fiction: A Critical Study. New Delhi, Pencraft International.

[2] Trilling, L. (2008). The liberal imagination. New York, New York Review Books Classics.

[3] Iyenger, K.R.S. (1985). The novel themes, backgrounds, types. In Indian Writing in English (chapter XVI). New Delhi, Sterling Publishers.

[4] Macaulay, T.B. (1835, February 2). Minute by the Hon'ble T.B. Macaulay. Retrieved February 1, 2018, from http://www.columbia.edu/itc/mealac/pritchett/00generallinks/ macaulay/txt_minute_education_1835.html

[5] Banerji, J. (1996, June - July). 'Bengali Braid' (review of The Calcutta Chromosome). Indian Review of Books, 5(9), 22-30.

[6] Bradbury, M. (1973). Possibilities: Essays on the state of the novel. London, Oxford Press University.

[7] Mondal, A.A. (2007). Amitav Ghosh. Manchester, Manchester University Press. https://doi. org/10.7228/manchester/9780719070044.001.0001

[8] Ghosh, A. (1995). The Calcutta chromosome. USA, Avon Books.

\section{Bio note:}

Dr. Manoj Kumar Pathak, Assistant Professor of the Department of English of the Arka Jain University. E-mail: mkp4ujsr@gmail.com.

\section{Сведения об авторе:}

Патхак Манодж Кумар, доктор наук, доцент кафедры английского языка Университета Арка Джайн. E-mail: mkp4ujsr@gmail.com. 